\title{
Socioantropologia do cinema: imaginários e signos alegóricos
}

\author{
Wendell Marcel Alves da Costa ${ }^{1}$
}

\section{Resumo}

Este artigo traz uma abordagem socioantropológica do cinema para tratar o cinema de ficção como acervo antropológico imaginário. Para isso, desenvolvo aproximações teóricas com Gaston Bachelard e Gilbert Durand, a fim refletir por meio de imagens fílmicas o potencial fenomenológico e imaginário do cinema de ficção. Apresento um arsenal teórico e metodológico que cruza a análise de filmes emblemáticos da cinematografia mundial para se referir à imaginação simbólica como acervo antropológico imaginário: dos sonhos, imaginários e imaginações das sociedades que imaginam o mundo e as coisas. Busco, portanto, uma pesquisa interdisciplinar engajada na investigação dos imaginários e signos alegóricos.

Palavras-chave: imaginários; signos alegóricos; cinema de ficção; socioantropologia; acervo antropológico.

\section{Cinema social-anthropology: imaginary and allegorical signs}

\section{Abstract}

This article brings a socio-anthropological approach to cinema to treat fictional cinema as an imaginary anthropological collection. For this, I develop theoretical approaches with Gaston Bachelard and Gilbert Durand, in order to reflect through film images the phenomenological and imaginary potential of fiction cinema. I present a theoretical and methodological arsenal that crosses the analysis of emblematic films of world cinematography to refer to the symbolic imagination as an imaginary anthropological collection: of dreams, imaginary and imaginations of societies that imagine the world and things. I therefore seek interdisciplinary research engaged in the investigation of allegorical imagery and signs.

Keywords: imaginary; allegorical signs; fictional cinema; socio-anthropology; anthropological collection.

\section{Introdução}

Este artigo trata o cinema de ficção como objeto em Antropologia. Filmes de ficção, que abraçam os gêneros drama, ficção científica, fantasia, aventura, entre outros, revelam o acervo imaginário das sociedades e culturas que retratam; são dotados de um aparato imaginário de convenções, códigos e imaginações sobre a vida social. Filmes documentários - que também são obras de ficção híbridas²

1 Doutorando no Programa de Pós-Graduação em Sociologia da Universidade de São Paulo (USP).

2 Ficção e documentário na linguagem cinematográfica. O filme, sendo documentário ou ficção, constrói e reproduz a realidade. 
- devotam de um pragmatismo acerca dos modelos de representação que muitas vezes são explorados nas narrativas cinematográficas. $\mathrm{Na}$ tentativa de expandir o campo da Antropologia do Cinema este artigo ilumina filmes de ficção - obras cinematográficas gêneros de ficção para problematizá-los como objeto de pesquisa no campo antropológico. A razão é que, comparativamente, filmes documentários a longo prazo se constituíram como objetos em Sociologia, Antropologia, Filosofia, Geografia, entre outras áreas, tornando-se inclusive instrumento de pesquisa nas Ciências Sociais.

São diversos os festivais de cinema nos congressos de entidades como Reunião Brasileira de Antropologia (RBA), Associação Nacional de Pós-Graduação e Pesquisa em Ciências Sociais (ANPOCS), Sociedade Brasileira de Sociologia (SBS), Reunião de Antropologia do Mercosul (RAM), Associação LatinoAmericana de Sociologia (ALAS), Associação Latino-Americana de Antropologia (ALA), International Union of Anthropological and Ethnological Sciences (IUAES) e Reunião Equatorial de Antropologia (REA/ABANNE). Esses congressos aceitam documentários nas programações, entretanto não possuem editais para filmes de ficção.

Neste trabalho não analiso a produção de filmes de ficção feitos por antropólogos como equipamentos de pesquisa. Entendo que a obra fílmica possa ser: (1) ferramenta de pesquisa por pesquisadores nas Ciências Sociais e (2) objeto de pesquisa para compreender como a sociedade é representada. No entanto, o recorte desta pesquisa centra nos filmes de ficção como objetos de pesquisa na Antropologia.

O debate sobre a pesquisa antropológica com filmes de ficção - podendo ser amplificado para o campo das Ciências Sociais - é comum nos espaços acadêmicos brasileiros. Mas pode ser mais amplo; ultrapassar os nichos acadêmicos, envolver o debate e a crítica, assim como a produção e circulação de obras de ficção.
Muitas vezes, as pesquisas são direcionadas para as áreas de produção, circulação, recepção e representação fílmica, sem, contudo, interpretar as dinâmicas internas e externas que a imagem fílmica repercute na fabricação imaginária dos discursos cinematográficos.

Neste sentido, o imaginário contribui para a construção da narrativa cinematográfica na medida em que estabelece padrões e modelos estéticos e filosóficos de pensamento do mundo. A obra fílmica é um olhar social e simbólico dos contornos da sociedade, costumes, pensamentos e imaginações sobre tempos e espaços sociais (CABRERA, 2006; SORLIN, 1977). Em um panorama geral, a antropóloga CaiubyNovaes (2009, p. 53) apresenta filmes de ficção como "documentários preciosos sobre nosso imaginário, sobre nossos valores e aspirações. Como antropólogos e cientistas sociais, interessanos o cinema como campo de expressão imagética de nossa realidade social". Explorar a dimensão social e simbólica dos filmes de ficção, feitos por não antropólogos, é um desafio corrente nos estudos de cinema e Antropologia. O problema reside, como apresento, nos meandros plásticos dos filmes de ficção. Para Eliska Altmann (2009, p. 63), “o estatuto 'mimético' da imagem parece ser uma das principais causas de sua desconfiança pela Antropologia”. A valoração do cinema como objeto em Antropologia está na admissão dos critérios verdade, tempo e autoria no fazer antropológico, distanciando do fazer fílmico o subjetivo ${ }^{3}$, prerrogativa que elimina a face estética do cinema.

Segundo Didi-Huberman (2012), a imagem como dispositivo do visível arde em seu contato com o real. Isso significa dizer que a imagem é aspiração simbólica do mundo. "Saber olhar uma imagem seria, de certo modo, tornar-se capaz de discernir o lugar onde arde, o lugar onde sua eventual beleza reserva um espaço a um 'sinal secreto', uma crise não apaziguada, um sintoma. O lugar onde a cinza não esfriou" 4 . Em sua leitura, ao analisar uma obra visual "primeiro suporá

3 Ibid.

4 Ibid., p. 215. 
suspense, a mudez provisória ante um objeto visual que o deixa desconcertado, despossuído de sua capacidade de lhe dar sentido, inclusive para descrevê-lo; logo, imporá a construção desse silêncio em um trabalho de linguagem capaz de operar uma crítica de seus próprios clichês" 5 . Disso vem o conhecimento da obra visual, ao conceder de mais um sentido o real.

Filmes de ficção contribuem para construção do acervo antropológico imaginário do mundo e das coisas (COSTA, 2019a). O cinema é uma arte do imaginário e pesquisar este imaginário é adentrar na complexa atividade humana de expressão das subjetividades. Não poderia fazer isso sem realizar uma socioantropologia do cinema, pois muitos são os paradigmas que a imagem fílmica apresenta para interpretação. Enquanto a Sociologia traz um aparato metodológico centrado na análise das fruições orgânicas ligadas às sociedades e processos de grupos, a Antropologia revoga o olhar subjetivista e temporal voltado para os sistemas culturais. Quero com isso resgatar o que Morin (2014) já abriu nos estudos cinematográficos: dotar o imaginário de empiria. No mesmo caminho, destaco a significativa potência dos signos alegóricos para a interpretação das representações das relações sociais (DURAND, 1997).

Os diretores de cinema, ao representarem as realidades sociais conjugam narrativas e o imaginário sobre ela e este elemento é, na verdade, o que faz do cinema uma expressão artística cultural de cunho simbólico e social. Em outro lugar defendi que cinema é "expressão artística cultural de envergadura simbólica pois a sétima arte ressignifica os códigos e as imaginações da vida privada e pública e as ilustra em formato de signos simbólicos nos filmes" (COSTA, 2019b, p. 98). Do mesmo modo, “o cinema será expressão artística de cunho social quando os agentes sociais necessitam auto representar ou representar biografias de vida e histórias da vida moderna"6. O verbo expressar transporta para a dimensão da projeção das subjetividades: exprimir, exibir, manifestar, articular. Expressar é uma propriedade da produção simbólica cinematográfica.

Com uma abordagem socioantropológica de envergadura filosófica problematizo filmes a partir da análise e interpretação fílmica sem intelectualizar seus discursos e narrativas por meio de teorias das Ciências Sociais (MENEZES, 1996). Por outro lado, procuro ler suas imagens, mensagens e códigos para entrar no discurso fílmico e na representação de ideias e pensamentos de mundo. O conteúdo estruturado pela linguagem do cinema é comunicado pelo discurso fílmico que é "uma prática que impomos ao mundo, que o organiza, que o recorta e monta para o nosso olhar e para o dos outros segundo valores e pressupostos, sejam eles pensados, explícitos, ou não" (MENEZES, 2017, p. 27). Por este motivo escolho realizar uma pesquisa socioantropológica de envergadura filosófica: desvendar as evidências simbólicas do discurso e das imagens fílmicas e creditar à fenomenologia fílmica um potente instrumento de empiria das sociedades representadas. Assim feito, entrarme-ei no cinema de ficção e seus imaginários e signos alegóricos, envolvido nos debates de Gaston Bachelard (1988a, 1993) e Gilbert Durand (1997), respectivamente, na imaginação sonhadora e signos alegóricos.

O artigo está dividido em três partes: (1) imaginação e o referencial teórico e conceitual, que por sua vez forma a socioantropologia do cinema; (2) relação entre cinema e Antropologia e a questão do espaço e tempo fílmicos para a modelação da imaginação e construção do discurso fílmico; (3) interpretações razoáveis sobre imagens fílmicas do universo e da juventude que fazem parte do acervo antropológico imaginário desses temas.

\section{Imaginação sonhadora, imaginários e signos alegóricos}


$\mathrm{O}$ ato de imaginar é dar sentido ao mundo e, para imaginar, é necessário aderir ao devaneio poético (BACHELARD, 1988a). Quando o artista devaneia, ele aciona mecanismos de interpretação do mundo, buscando organizar simbolicamente convicções sobre os modos como as pessoas se comportam na sociedade, a penetração da política na vida das pessoas, o medo de morrer, a alegria de ver alguém nascer. A organização não é lógica e tampouco sincrônica, o devaneio não estabelece fronteiras para o pensamento. Entrando no imaginário como possibilidade imaginativa de pensar o mundo , e ao pensar buscar nele uma ideia de como é imaginada e sonhada a realidade, Bachelard (2001, p. 29) propõe "para fundar uma psicologia da imaginação, partir sistematicamente do sonho e descobrir assim, antes das formas das imagens, seu verdadeiro elemento e seu verdadeiro movimento". Acrescentando: "por entre dores e territórios abandonados pelas imagens, se constrói a liberdade poética, trazendo consigo correntes de esperança, embebidas na força do imaginário como um unguento para enfrentar racionalismos mortificantes" (SAMPAIO; DUARTE, 2015, p. 138).

Em contrapartida, Araújo e Teixeira (2009) dissertam que existe uma dicotomia da imagem. Ao mesmo tempo em que a imagem desperta o interesse do espectador pelo caráter quase mágico da visualidade, por sua presença pictórica, é igualmente colocada no lugar da dúvida imanente ao seu estatuto mimético. Nesse ponto

A sociedade presente mantém com a imagem uma relação ambivalente: por um lado, tem com a imagem uma relação idolátrica, graças ao progresso de produção e reprodução da comunicação das imagens e, por outro, mantém uma relação de desconfiança, quase iconoclasta, pois não entende que ela própria esteja sedenta de imagens e de sonhos que apalavrem a sua "alma malhada", como diria Gilbert Durand, nem tão pouco que a imagem se possa abrir ao infinito numa inesgotável contemplação ${ }^{7}$.

Para Bachelard (1988a, 1993), o pensamento é resultado da imaginação sonhadora e criadora do ser humano que, ao imaginar, reproduz elementos do imaginário. Como o imaginário, em seu sentido amplo, são imagens produzidas por atividades da imaginação, o cinema de ficção ao mostrar visões da sociedade e da cultura contribui para descortinar ideias, como se fossem revelações do inconsciente, que se apresentam como matéria ao espectador. Segundo o autor, "para bem sentir o papel imaginante da linguagem [cinematográfica, em nosso caso], é preciso procurar pacientemente, a propósito de todas as palavras [cenas], os desejos de alteridade [verossimilhança], os desejos de duplo sentido [mensagens], os desejos de metáfora [significantes]" (BACHELARD, 2001, p. 3). Colocando em linhas curtas, "a verdadeira viagem da imaginação é a viagem ao país do imaginário, no próprio domínio do imaginário"8.

Assim, imaginação sonhadora é esvaziar as possibilidades do pensamento, emergir no espírito do devir, abraçar a filosofia do repouso (BACHELARD, 1988b).

$\mathrm{Na}$ esteira bachelardiana, Wunenburger e Araújo (2003, p. 25, sic) comentam que:

A análise do imaginário pode [...] efetuar-se quer por uma via negativa, na ciência, que apreende a imagem como obstáculo epistemológico, quer segundo uma abordagem positiva, sob a forma de poética geral, que a apreende como uma fonte criadora. As imagens que se impõem como obstáculos à abstração revelam-se, pelo contrário, positivas para o sonho, que é desta forma exatamente o oposto da ciência. [...] O poder da imaginação, no sentido de faculdade de deformar as imagens, enraíza-se efetivamente nas profundezas do ser.

Sabendo que "o valor de uma imagem se mede pela extensão de sua aura imaginária” (PITTA, 2005, p. 16), a preponderância do mito na teoria durandiana é exemplificada em sua concepção

7 Ibid., p. 7.

8 Ibid., p. 5. 
de "trajetória antropológica". Por mito entendese "sistema dinâmico de símbolos, arquétipos e schèmes que tende a se compor em relato", sendo "relato fundante da cultura: ele vai estabelecer as relações entre [...] os homens e o universo, entre os homens entre si. [...] É ainda função do mito fornecer modelos de comportamentos, permitir a construção individual e coletiva da identidade", enquanto que por "trajeto antropológico" compreende-se como "o incessante intercâmbio existente, ao nível do imaginário, entre as pulsões subjetivas e assimiladoras $\mathrm{e}$ as intimações objetivas que emanam do meio cósmico e social" 10 .

\section{Nesse contexto,}

Durand (1989) defende que o imaginário deve a sua eficácia a uma ligação indissolúvel entre, por um lado, estruturas que permitem reduzir a diversidade das produções singulares de imagens a alguns conjuntos isomorfos e, por outro lado, significações simbólicas, reguladas por um número finito de schèmes, de arquétipos e de símbolos. [...] A expressão privilegiada das imagens encontrase, contudo, no mito, cujas imagens seguem a sequência linguística: verbo, substantivo e adjetivo, sendo a função de substantivação nominal tida como secundária em relação ao verbo, verdadeira matriz arquetípica, ou em relação aos atributos que declinam a pluralidade intrínseca do sujeito ${ }^{11}$.

\section{Durand (1997) examina a estrutura} antropológica do imaginário ao denotar os símbolos da intimidade a partir dos regimes noturno e diurno. Em seu entender, as casas, escadas, degraus, cavernas e choupanas representam imagens do guardado, seguro e afetivo. $\mathrm{O}$ autor recomenda pensar os símbolos da intimidade pelo aspecto psicológico, seus esquemas e gestos. Os símbolos dos sacos, das navegações, das cascas de noz, das excreções nas verticalidades e horizontalidades remetem a todo uma estrutura de signos fundamentais para a estrutura do imaginário. Durand advoga ${ }^{12}$ que gestos "diferenciados em esquemas vão determinar, em contato com o ambiente natural e social, os grandes arquétipos mais ou menos como Jung os definiu. Os arquétipos constituem as substantificações dos esquemas".

Isto é, "trajetória antropológica" verifica-se na perpetuação de certos tipos de esquemas e gestos em rituais da realidade ou da produção artística. No nível pedagógico da formação do imaginário, têm-se o ambiente geográfico, o nível dos jogos e das aprendizagens, e o nível "sintomático", "ou o grau dos símbolos e alegorias convencionais determinados pela sociedade para a boa comunicação dos seus membros entre si" (DURAND, 2004, p. 91).

O "trajeto antropológico" representa a afirmação na qual o símbolo deve participar de forma indissolúvel para emergir numa espécie de "vaivém" contínuo nas raízes inatas da representação do sapiens e, na outra "ponta", nas várias interpelações do meio cósmico e social. Na formulação do imaginário, a lei do "trajeto antropológico", típica de uma lei sistêmica, mostra muito bem a complementaridade existente entre o status das aptidões inatas do sapiens, a repartição dos arquétipos verbais nas estruturas “dominantes" e os complementos pedagógicos exigidos pela neotenia ${ }^{13}$ humana $^{14}$.

Logo,

Os processos do mito, onírico ou do sonho consistem na repetição (a sincronicidade) das ligações simbólicas que os compõem. Por conseguinte, a redundância aponta sempre para um "mitema". Cada mitema - ou cada ato ritual - é o portador de uma mesma verdade relativa à totalidade do mito ou do rito. O mitema comporta-se como um holograma (Edgar Morin) no qual cada fragmento

9 Ibid., p. 18.

10 Ibid., p. 20.

11 ARAÜJO; TEIXEIRA, op. cit., p. 9, sic.

12 Ibid., p. 60.

13 Aprendizagens na infância que se estruturam na juventude. Capacidade de obter conhecimento e criar.

14 Ibid., p. 90. 
e cada parte contém em si a totalidade do objeto. Portanto, o imaginário, nas suas manifestações mais típicas (o sonho, o onírico, o rito, o mito, a narrativa da imaginação etc.) e em relação à lógica ocidental desde Aristóteles, quando não a partir de Sócrates, é alógico ${ }^{15}$.

Ciente de que "os conteúdos imaginários (os sonhos, desejos, mitos etc.) de uma sociedade nascem durante um percurso temporal e um fluxo confuso [...] para finalmente se racionalizarem numa 'teatralização' [...] de usos 'legalizados' [...], os quais recebem suas estruturas e seus valores das várias 'confluências' sociais"'16, os signos alegóricos duram espacial e temporalmente na confecção dos relatos culturais. No cinema, a presença de signos alegóricos emerge na complexidade da mensagem, iluminando objetos ou pessoas a fim de potencializar o discurso a ser originado. Signos alegóricos não possuem sons ou imagens objetivas, são propriedades do devaneio, portanto, são fenômenos que recaem sob ideologias a serem lançadas ao leitor/ espectador/receptor.

Sucintamente,

O imaginário, assim enraizado num sujeito complexo não redutível às suas percepções, não se desenvolve, todavia, em torno de imagens livres, mas impõe-lhes uma lógica, uma estruturação, que faz do imaginário um 'mundo' de representações. [...] As figuras do imaginário, nomeadamente o mito, dão-se a conhecer pela repetição, pela redundância quer dos seus temas, quer das suas sequências simbólicas. [...] O imaginário, devedor da imaginação criadora, visa a transformação eufêmica do mundo e, na qualidade de intellectus sanctus, procura subordinar o ser às ordens do melhor. É, pois neste último que reside o projeto da função fantástica e, por conseguinte, é este mesmo projeto que ajuda quer a compreender melhor os estados de consciência, quer a hierarquizar as faculdades da alma ${ }^{17}$.
Posso resumir dizendo que o cinema de ficção é um dos dispositivos culturais mais notáveis para a continuidade da "trajetória antropológica". Ao utilizar-se dos gestos, criando imaginários, filmes de ficção inventam narrativas dos sonhos e desejos, questionando o passado, traduzindo o presente e criando o futuro. Assim, signos alegóricos em filmes de ficção servem como componentes essenciais de simbolização. Como apontado por Durand (1997, 1993), o museu imaginário formado por símbolos, esquemas, signos, metáforas, alegorias e gestos conformam a identidade imaginativa do cinema para fazer o acervo antropológico imaginário. Desse modo, é inevitável a relação entre Antropologia e cinema de ficção.

\section{Aproximações entre Antropologia e Cinema}

Comumente as formas expressivas de recriação da realidade são concebidas como gramáticas motoras da representação simbólica da realidade; como se a realidade por si só não fosse uma representação do mundo social. Quando a Antropologia e os antropólogos olham para a imaginação criadora e sonhadora - nos termos de Bachelard e Corbin - as preocupações são com os rituais, mitos, convenções, ações simbólicas, representações na ordem do contexto (TURNER, 2008; GOFFMAN, 1985).

A utilização de imagens fotográficas para a pesquisa de campo esteve presente desde a inscrição de Malinowski entre os trobriandeses e seus rituais de trocas, passando por registros imagéticos do ethos balinês com Mead e Bateson. No caso desses últimos, a prancha fotográfica proposta pelos antropólogos visava trabalhar a dinâmica do olhar, a posição de um modelo sequencial de fotografias que contam uma história cultural. No âmbito do audiovisual, a imagem simbólica dos filmes de ficção traz à tona o que o texto escrito antropológico não traz: o

15 Ibid., p. 86-87.

16 Ibid., p. 96.

17 ARAÚJO; TEIXEIRA, op. cit., p. 10-11, sic. 
elemento de ideação. Nesse propósito, Rocha e Eckert (2015) acreditam na possibilidade de uma Antropologia voltada para a instrumentalização audiovisual dos pesquisadores. Tanto como instrumento na pesquisa antropológica como sendo objeto de pesquisa em Antropologia, filmes de ficção despertam o interesse da área. Assim, a relação entre Antropologia e cinema passa por essa intersecção: o cinema como instrumento e como objeto de pesquisa.

Em Antropologia, a crítica às tecnologias sofre, muitas vezes, as limitações do racismo caracterológico, oriundo do empirismo lógico, que impregna os saberes antropológicos e que tende a reduzir as peripécias semânticas ao universo concreto de suas técnicas. [...] O emprego dos meios audiovisuais nas etnografias estaria, assim, perigosamente preso às armadilhas de uma ordem lógica linear, situada na superfície da narrativa, em que as regras e os modelos das estruturas operatórias naturais do pensamento e da linguagem são reivindicados em detrimento das estruturas formais do pensamento, que fazem com que aquilo que está sendo narrado adquira autonomia e fecundidade próprias $^{18}$.

Ademais,

A imagem é outra coisa que um simples corte praticado no mundo dos aspectos visíveis. É uma impressão, um rastro, um traço visual do tempo que quis tocar, mas também de outros tempos suplementares - fatalmente anacrônicos, heterogêneos entre eles - que não pode, como arte de memória, não pode aglutinar. É cinza mesclada de vários braseiros, mais ou menos ardentes ${ }^{19}$.

Nesse entendimento, a obra de ficção como representação do mundo pode ser objeto na pesquisa antropológica, assim como serve à produção do conhecimento antropológico como ferramenta audiovisual. É preciso afiar- se que a imagem simbólica dos filmes de ficção tem força na fabricação mimética da realidade, inclusive nas representações sociais originadas no ambiente social. As representações não surgem do nada, são ações enraizadas de gestos, de influências construídas no interior de suas formas e passadas a frente pelas pessoas. Este é o lado mais conhecido do uso de filmes de ficção no campo do conhecimento antropológico, o da representação e reprodução da realidade.

Myrian Santos (2000), ao discutir as intenções narrativas de dois filmes sobre a peça Orfeu Negro nos anos 1950 e 1990 argumentou que existe um limiar antropológico entre fantasia e realidade. As formas representacionais dos dois filmes repercutem noções imaginárias sobre a história contada. Em sua leitura, "os filmes apresentam visões unilaterais de fenômenos sociais e expressam muitos mitos presentes nas épocas em que foram produzidos. [...] São capazes de transcender os limites das análises associadas a cada período histórico" ${ }^{20}$. De forma mais geral, "as produções cinematográficas detêm um potencial estético expressivo que poderá ser relevante se considerados seus limites e a parcialidade tanto das produções cinematográfica, quanto da análise que estará sendo realizada de descrição da realidade" 21 . Isto posto, a representação da realidade é parte do discurso cinematográfico, o outro lado, menos tratado, é o da produção da realidade.

Tratando-se da relação histórica entre Antropologia e imagem, nos anos 1990 a antropologia visual "enquanto campo de reflexão metodológica, ainda não encontrou sua autonomia e aceitação nas áreas de ensino e pesquisa no Brasil. Sua adequação e aplicação aos princípios da teoria antropológica estão ainda longe de serem adotados na maioria das instituições, [...] seu espaço de discussão é bastante restrito" (PEIXOTO, 1995, p. 77-78). O desafio continua: compartilhar formas de fazer e pesquisar filmes de ficção e relacionar com a teoria

18 Ibid., p. 140.

19 DIDI-HUBERMAN, op. cit., p. 216.

20 Ibid., p. 45.

21 Ibid., p. 45. 
antropológica e das Ciências Sociais. O filme de ficção preenche os espaços da imaginação sobre aspectos simples e cotidianos. Para pesquisar o objeto cinematográfico, a socioantropologia do cinema se relaciona com a Filosofia e a Geografia Cultural, considerando a análise sociológica de filmes a partir de um aparato conceitual interdisciplinar (MENEZES, 2017).

Nos estudos da imagem são muitas as vertentes da Antropologia: Antropologia da Imagem, Antropologia Audiovisual, Antropologia Visual, Antropologia do Cinema, Antropologia do Tempo e do Espaço, Etnografia Fílmica, Etnografia Visual, Etnografia da Imagem, entre outras. Para além das diversas nomenclaturas, que parecem falar do mesmo objeto, a imagem, com suas variedades de tempos e espaços simbólicos, a Antropologia do Cinema é o campo que estuda os imaginários, imaginações, signos alegóricos, arquétipos, símbolos e estruturas simbólicas organizadas por códigos, mitos, signos, tempos, espaços e dinâmicas internas criadas pela linguagem cinematográfica. A reunião desses princípios faz o discurso cinematográfico, que pode referir-se ou não a sociedade e cultura imaginada.

Na perspectiva de Hikiji (2012, p. 55-56),

Filmes ficcionais são formas de recorte, apreensão e organização do mundo. As imagens contam histórias, falam de tempos, lugares, sentimentos, perspectivas. Os filmes registram mitos e também mitificam representações. Sintetizam uma série de visões de mundo. Filmes, como mitos, são narrativas social e culturalmente construídas. Não são relatos realistas, mas "dramatizações" da realidade. O filme, como um mito, relaciona-se com a realidade de forma dialética, estabelecendo parâmetros ao espectador.

Se o filme de ficção é um mito ${ }^{22}$, então pode ser lido como construção social e cultural da realidade no domínio da imaginação e criação de mundos sociais. Nos contornos do filme deve haver a presença do "mito manifesto", aquele que "deixa passar o conjunto de valores e ideologias oficiais" (DURAND, 2004, p. 97-98), para efeito de análise socioantropológica. No cinema de ficção, imaginários e signos alegóricos são tópicos para se reconhecer a realidade por meio da imaginação criadora. As imagens da realidade registradas pelo aparelho cinematográfico são performáticas e o aparelho cinematográfico esculpe o tempo e o espaço fílmicos. O termo híbrido insere-se nestes dilemas conceituais. Morin $^{23}$ tem se questionado sistematicamente sobre a imagem e a representação, mas é enfático em afirmar que "a única realidade da qual temos certeza é a representação, ou seja, a imagem, ou seja, a não realidade, já que a imagem remete a uma realidade desconhecida". Conforme Menezes (2017, p. 27), é fundamental "não esquecer em nenhum momento que um filme é um discurso fílmico. Assim, ele é mais do que apenas a posição de seu diretor ou produtor. Ele é um discurso no sentido forte do termo, partindo de determinadas percepções de mundo que são historicamente marcadas e datadas".

É possível considerar diretores de cinema etnógrafos que foram persuadidos pelo arsenal simbólico restituídos ao cinema de ficção? Eles serão - além dos documentaristas-antropólogos como Jean Rouch (Crônica de Um Verão, 1961) e Robert J. Flaherty (Nanook, o Esquimó, 1922) - intérpretes da cultura. Claramente o debate se estende para os limites deste artigo; mas como já indiquei, a crítica da área tem permanecido na adequação aos regimes de verdade, tempo e autoria $^{24}$. É de bom tom circular que "muitos dos filmes 'etnográficos' acabaram por 'documentar' os traços da aventura temporal humana que constitui o trabalho antropológico, explorando [...] os procedimentos de interpretação do mundo que comportam tais tecnologias e de sua feição de máquinas criadas no sentido da exteriorização de processos mentais" (ROCHA; ECKERT, 2001, 
p. 4). A linguagem cinematográfica esculpi o que filma, embalsama temporalmente os gestos humanos, sobrepõe os medos humanos em imagens palimpsestos. O cinema de ficção é coisa mundana, profana e sobrenatural; nada escapa à agressividade do aparelho cinematográfico que projeta com delicadeza a luz do mundo.

Isso porque, no contato entre realidade e ficção,

Em Antropologia visual, a arte da ficção pode estar dissimulada sob o véu de uma motivação realista, segundo a qual a etnografia visual aparece não só como semelhança com o real, mas com o verdadeiro, e em que a imagem técnica não foge ao solo fértil da imaginação criadora do(a) pesquisador(a), sendo tratada como miniaturização do mundo. Sob este ângulo, as obras etnográficas geradas no âmbito da Antropologia visual tendem a perder a sua força criadora pela tendência a submeter as imagens, no corpo de uma narrativa, a cadeias lineares e homogêneas de sentido, pelas quais o pluralismo de suas conexões simbólicas cede lugar à intenção do(a) antropólogo(a) em agrupá-las segundo cifras normalizadas por um logos abstrato e vazio e delas retirar a identidade dos dados empíricos apresentados (ROCHA; ECKERT, 2015, p. 159).

Carlos Reyna afirma ser possível conceber a Antropologia do Cinema como um campo de atuação de etnógrafos de filmes, quando no seu entendimento "o filme como uma teia de significados, texto audiovisual, em se propõe uma análise que interprete os significados para sujeitos e atores sociais da ação. [...] Uma reflexão e interpretação das representações culturais desse homem por meio da imagem", assim "a antropologia do cinema tem por objeto a imagem do homem tanto quanto o homem" (REYNA, 2017, p. 47).

Nesse aspecto, para destinar o olhar sobre uma Antropologia do Cinema, de pesquisar as imagens fílmicas e suas representações incido em uma Antropologia que se volta para o homem imaginário $^{25}$. O homem é imaginado e produz imaginações sobre si mesmo pelo ato da expressão. O cinema atua em e sob ele, para falar sobre o seu entorno - seu contexto e sua cultura - e seu interior - sua subjetividade e sua existência. É o homem imaginário que o cinema tem talhado há mais de 120 anos: em todos os cantos do mundo, é a imagem do homem e das suas invenções. Tudo o que o homem faz e imagina funciona como matéria para a fabricação das histórias dos filmes.

Não que o cinema seja uma forma de arte antropocêntrica, mas que, em razão dos instrumentos - o aparelho cinematográfico -, dos artistas - os diretores de cinema e sua equipe -, do público-alvo - os espectadores de cinema - e comumente do seu alvo de filmagem - o ser humano e tudo aquilo que ele produz - o início, o meio e o fim seja o homem. Daqui surge o homem imaginário: o cinema é uma arte feita por homens e mulheres, para homens e mulheres, sobre homens e mulheres. Destarte, o cinema mostra o contorno e o entorno do ser social. E "felizmente e apesar de tudo, [...] uma minoria de pesquisadores, que cresce a cada dia, interessouse pelo estudo deste fenômeno [das imagens e das manipulações icônicas] fundamental da sociedade e pela revolução cultural que implica" (DURAND, 2004, p. 34).

\section{Cinema e acervo antropológico imaginário: entrada}

O cinema é capaz de produzir/reproduzir mundos espetaculares, utopias, fenômenos que existiriam apenas na imaginação humana. É capaz de fabricar histórias comuns, cotidianas, ligadas ou não ao tempo cronológico da vida "real". Por meio de uma linguagem que se estrutura enquanto método e procedimento, o cinema se reorganiza no exercício da filmagem: é no set do filme, no caso dos filmes de ficção, que tudo acontece. No entendimento de Bazin (2018, p. 31), a fotografia trouxe a novidade de poder esculpir o tempo como instituição embalsamadora da realidade objetiva, atividade 
que a pintura não foi capaz de realizar, de suprir "a satisfação completa do nosso afã de ilusão por uma reprodução mecânica da qual o homem se achava excluído". Já o cinema, com sua linguagem, esculpe o mundo (TARKOVSKI, 2010).

Com igual justificativa,

Certamente o imaginário não estabelece [...] fronteiras firmes e discerníveis entre o real e o irreal, por isso se justifica tal intenção em refletir a partir de um cruzamento entre a tomada de consciência do processo fenomenológico e abertura fértil e apaixonada do domínio da imaginação. Dessa forma, descobrimos com Bachelard um método de reexaminar imagens amadas, de mergulhar em filmes que nos tocaram e os deixamos perder nas curvas da memória ${ }^{26}$.

Para falar de cinema de ficção como acervo antropológico imaginário, cito Georges Méliès, ilusionista e cineasta francês do final do século XIX, pioneiro no uso de técnicas e narrativas cinematográficas - como a técnica stop-motion e a dissolução de imagem na película fílmica para construir mundos imaginários baseados nas histórias de Jules Verne. Sua obra máxima, Viagem à Lua (Georges Méliès, 1902), embarcou os espectadores em uma missão que só foi possível graças a uma série de elementos que incluía arranjos inovadores de montagem e direção de arte. Suas criações jogavam com a imaginação e os sonhos.

À exemplo de Viagem à Lua, inúmeros filmes representaram a noção imaginal do universo a partir de figuras arquetípicas do céu contadas nos livros - como as fábulas - e nos filmes. No século $\mathrm{XX}$, imaginar o universo se tornou com o tempo uma operação que almejava a ir além de onde se está; buscar o desconhecido, concretizar em "realidade audiovisual" - nossas percepções mais exploradas - aquilo que os cientistas e artistas do Renascimento chegaram a esboçar nos cadernos de anotações. Tentativas clássicas no campo do cinema, em imaginar como o universo intercala os sonhos noturnos (BACHELARD, 1988) com a filosofia existencial (SARTRE, 1987), é 2001: Uma Odisseia no Espaço (Stanley Kubrick, 1968) que serviu como objeto-imaginário da ideia de universo (Figura 1). O filme é produto da adaptação cinematográfica do conto homônimo de Arthur C. Clarke, Sentinel of Eternity, publicado originalmente em 1951.

A obra ganhou notoriedade após a divulgação de 2001: Uma Odisseia no Espaço, chegando a ser transformado em livro posteriormente. Desde Viagem à Lua, o cinema de ficção científica expõe a missão de homens em ultrapassar a atmosfera em direção ao universo: este desejo de ir mais além se aproxima à ideia de homo demens, o fabricador de imaginações, mitos, inventor de sua realidade onírica. O longa-metragem de Kubrick, apesar das distâncias temáticas e de gênero pode ser comparado com a iniciativa pioneira de Méliès, quando em 1902 preconizou um olhar sonhador para a vida na lua, para realidades além da terrestre.
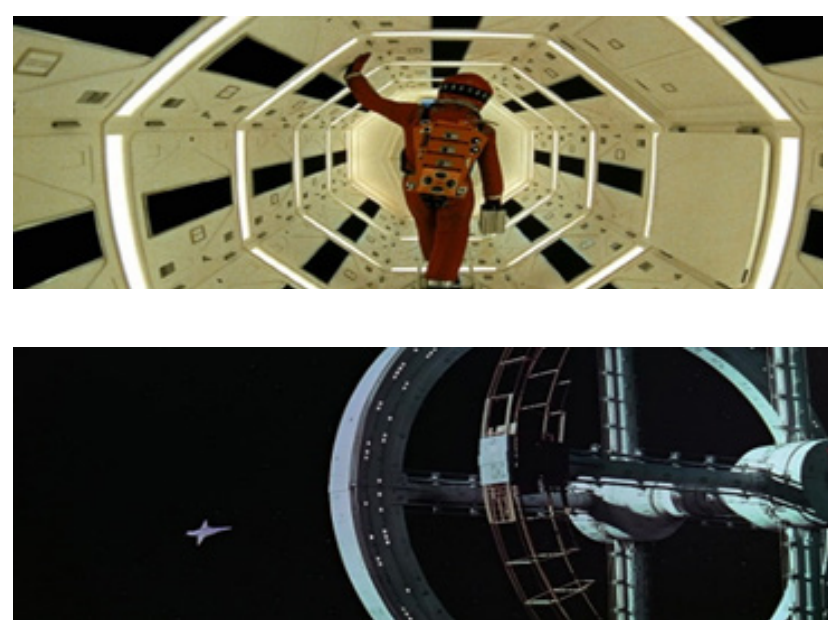

Figura 1 - frames de 2001: Uma Odisseia no Espaço. Fonte: Stanley Kubrick Productions.

Méliès acreditava na potência da imaginação, que o sonho poderia ser igualmente um enredo para a criação de filmes como Viagem Através do Impossível (Georges Méliès, 1904), que explorou diversos gêneros cinematográficos: aventura, ficção científica, fantasia. Nesta obra, um grupo de geógrafos viajam pelo mundo em um trem a procura de aventuras, mas depois de um acidente em um dos vagões as pessoas são hospitalizadas 
(Figura 2). Em seguida, sobem até o céu no trem voador e adentram pela boca do sol no mundo vermelho que queima, mas não mata. $\mathrm{Na}$ descida de volta à terra são congelados. O filme representa noções imaginárias de como seria ir e voltar de uma viagem extraordinária até ao sol.
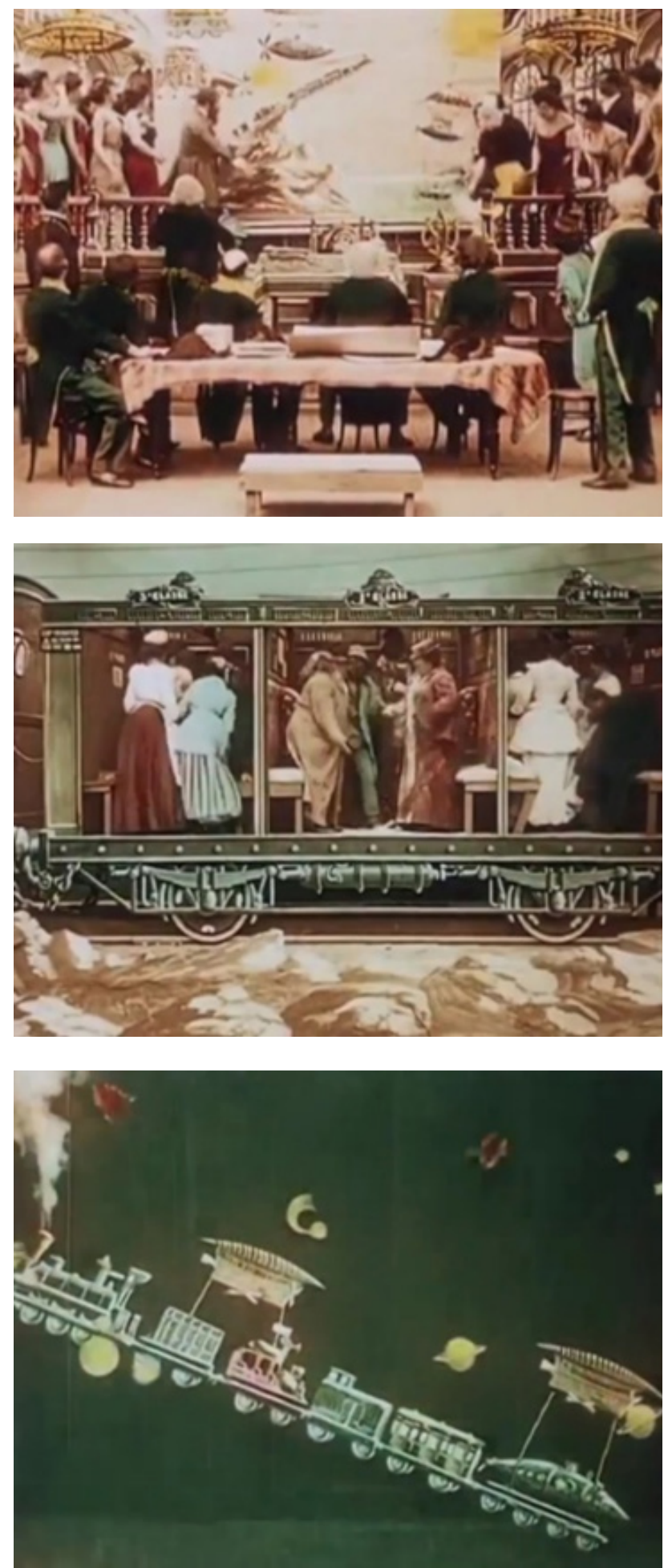

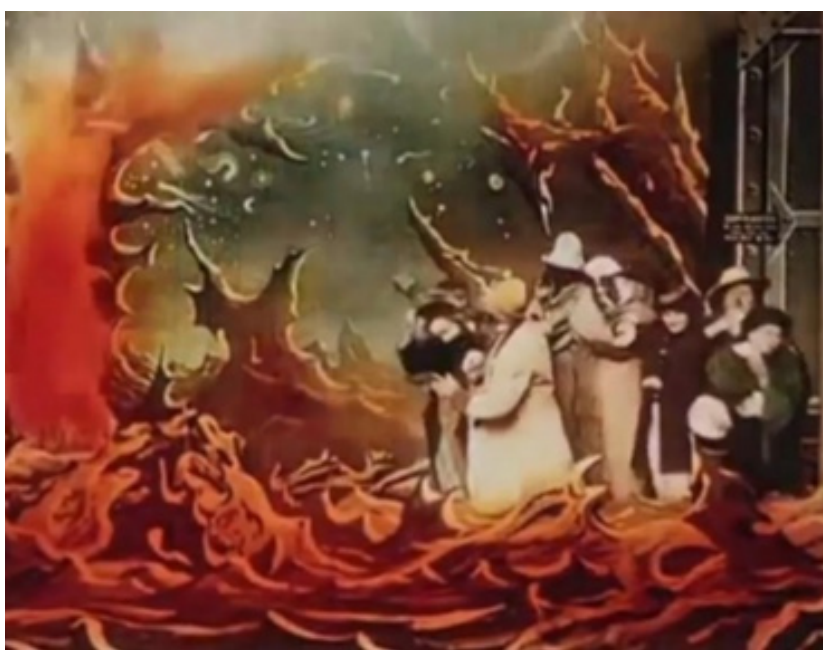

Figura 2 - frames do filme Viagem Através do Impossível. Fonte: Georges Méliès Productions.

A Figura 2 mostra algumas das passagens mais emblemáticas do filme, que foi pintado à mão quadro por quadro, iniciativa pioneira do mágico francês. O cinema de Méliès conseguiu com recursos inéditos arranjar duas percepções de cinema: uma, a atração sobre o espetacular - encenar situações nunca antes vistas - e a outra, na fantasia, concretizar a verossimilhança dos enredos - mesmo histórias fantasiosas, são representações do sonho e das vontades humanas. Assim como em Viagem à Lua, os personagens do filme Viagem Através do Impossível vivem aventuras trazidas pelo progresso científico e tecnológico da vida moderna que não foram vividas por outras pessoas. Viagem Através do Impossível evoca a imagem do trem urbano que leva as pessoas para caminhos na Terra e no céu, já presente no imaginário dos espectadores de cinema da época em filmes criadores desta noção imaginária: A Chegada de Um Trem à Estação (Auguste e Louis Lumière, 1895), The Kiss (George Albert Smith, 1899), O Grande Roubo do Trem (Edwin Porter, 1903) e, duas décadas depois, $A$ General (Buster Keaton, 1926). A figura do trem agora presente no imaginário social presentifica a instituição da modernidade trazendo movimento, fluxo e relações temporalmente modificadas às vidas cotidianas das pessoas, um exemplo do acervo antropológico imaginário.

\section{Tempo e espaço fílmicos}


No primeiro cinema, filmes podem ser considerados como tecnologias sociais de descobrimento. Os irmãos Lumière foram responsáveis por gravar o cotidiano das pessoas em lugares de fluxo, representativos da modernidade industrial da França do final do século XIX. Suas imagens urbanas cotidianas mostram os caminhantes (CERTEAU, 2014), que mesmo na objetividade da câmera cinematográfica elas tangenciam a imanência do ficcional que a linguagem cinematográfica infere à imagem filmada - a posição fixa da câmera, as pessoas que passam no quadro, o tempo de filmagem, são técnicas do cinema de ficção no primeiro cinema. O cinema de ficção feito por Méliès registra a imaginação e uma percepção humana.

$\mathrm{O}$ precursor Méliès considerou remodelar o espaço fílmico para alcançar uma narrativa cinematográfica. Como pode ser visualizado na Figura 2, os atos vão se construindo na mudança dos espaços fílmicos de filmagem, na admissão de novos setores cênicos de representação dos atores. Os filmes do norte-americano D.W. Griffith, diretor dos filmes O Nascimento de Uma Nação (1915) e Intolerância (1916), desenvolveram técnicas de plano e montagem. Menos lembrado que Lumière e Méliès, Griffith consagrou o que se entende hoje por linguagem cinematográfica, principalmente ao tratamento dado a montagem e profundidade de campo, influenciando cineastas como Lewis Milestone (Sem Novidade no Front, 1930), Fritz Lang (M, O Vampiro de Dusseldorf, 1931) e Jean Renoir (A Grande Ilusão, 1937).

No aspecto do cinema como instituição ideológica de imagens que retratam evidências audiovisuais reais e ficcionais (COSTA, 2003), para Pudovkin (2018, p. 60) "o diretor de cinema [...] pode concentrar, temporalmente, não apenas incidentes separados, mas até mesmo os movimentos de uma única pessoa. Este processo
[...] é, na verdade, nada mais do que o método característico de representação fílmica”. Em Viagem Através do Impossível, tempo e espaço fílmicos sofrem alteração com o objetivo de assegurar o teor fantástico. O espectador é convidado para viver num tempo fílmico que é diferenciado daquele da realidade "pela sua exclusiva dependência dos comprimentos dos pedaços de celuloide que são unidos pelo diretor $^{27},[\ldots]$ o espaço fílmico aparece como uma síntese dos elementos reais registrados pela câmera"28.

O exercício de reconstruir a realidade pelo trabalho com o tempo e o espaço fílmicos consagra-se com o trabalho da memória e da imaginação. Os filmes, quando são exibidos, contam histórias e nesse processo de enunciação do discurso fílmico o tempo e o espaço fílmicos vão se cruzando no passado e no presente dos personagens para chegar até aos espectadores da sala escura do cinema. Idem, os espectadores de cinema possuem uma história pessoal, que é acionada no ato da exibição dos filmes, fazendo com que os espectadores sejam coparticipantes na criação de leituras das mensagens fílmicas.

\begin{abstract}
No cinema, a imaginação se projeta na tela. A cena final da ruína entra justamente ali onde a vitória parece mais gloriosa, estabelecendo o estranho contraste; cinco segundos após retoma-se o fio da juventude e do entusiasmo. [...] O cinema pode agir de forma análoga à imaginação: ele possui a mobilidade das ideias, que não estão subordinadas às exigências concretas dos acontecimentos externos, mas às leis psicológicas da associação de ideias. Dentro da mente, o passado e o futuro se entrelaçam com o presente. O cinema, ao invés de obedecer às leis do mundo exterior, obedece às da mente (MUNSTERBERG, 2018, p. 34-35, sic).
\end{abstract}

Esse processo imaginativo é resultado das atividades do diretor de cinema e sua equipe.

27 É comum nos filmes o diretor fazer a montagem (edição) completa da obra. Contudo, existem inúmeros casos em que um montador (editor) fica responsável por esta atividade, sozinho ou acompanhado pelo diretor do filme. No período chamado primeiro cinema (COSTA, 2006), a montagem do filme era feita quase que exclusivamente pelo diretor - que fazia a produção, roteiro, fotografia e atuava, como é o caso de Charles Chaplin.

28 Ibid., p. 61 
São capazes de projetar a imaginação por meio de imagens tradicionalmente ordenadas em vinte quatro quadros por segundo. Entre os primeiros diretores, de 1894 a 1907, a imaginação sonhadora tornou-se matéria-prima para as histórias dos filmes; nada seria impossível para os artistas de cinema que viam a sétima arte como um canal para apresentar diversão e entretenimento em objeto visual e com movimento. "Sua imaginação identifica a ideia cinematográfica com uma representação total e integral da realidade; ela tem em vista, de saída, a restituição de uma ilusão perfeita do mundo exterior, com o som, a cor e o relevo" (BAZIN, 2018, p. 39), com as técnicas que fariam da linguagem cinematográfica diferente da do teatro ou da música, ou de qualquer outra representação artística. Mas a projeção de imagens na tela grande não é totalmente nutrida pelas leis da mente ${ }^{29}$, visto a presença dos artefatos e visões do mundo exterior. Esse é um dos paradigmas do cinema: expressão da mente e "espelho" do mundo exterior.

Nas palavras de Bazin (2018, p. 40-41),

O mito diretor da invenção do cinema é, portanto, a realização daquele que domina confusamente todas as técnicas de reprodução mecânica da realidade que apareceram no século XIX, da fotografia ao fonógrafo. [...] Se o cinema nasceu, isso se deve à convergência da obsessão deles; isto é, de um mito: o do cinema total.

Como investigar cientificamente filmes a partir de imagens construídas pela linguagem cinematográfica? Bazin já dizia que cinema é linguagem, diferindo da fotografia em razão de sua organização lógica e material. Martin (2013) em seu livro central sobre linguagem cinematográfica discute dezenas de filmes, passando pelos gêneros e movimentos cinematográficos para desenvolver sobre o que faz do cinema, cinema. $\mathrm{O}$ autor pontua sobre a originalidade da linguagem cinematográfica em desenrolar por meio das narrativas fílmicas imagens sobre documentos, memórias, sentimentos, vivências. Segundo ele, o cinema não mostra os objetos, mas as imagens dos objetos, suas sombras e suas presenças que fundam as camadas simbólicas das películas.

No cinema,

Tal originalidade advém essencialmente de sua onipotência figurativa e evocadora, de sua capacidade única e infinita de mostrar o invisível tão bem quanto o visível, de visualizar o pensamento juntamente com o vivido, de lograr a compenetração do sonho e do real, do impulso imaginativo e da prova documental, de ressuscitar o passado e atualizar o futuro, de conferir a uma imagem fugaz mais pregnância persuasiva do que o espetáculo do cotidiano é capaz de oferecer ${ }^{30}$.

Como o diretor de cinema opera sensações humanas e situações sociais - mesmo aquelas de ficção científica que carregam vinculações com as questões sociais, como Planeta dos Macacos (Franklin J. Schaffner, 1968) e Blade Runner - O caçador de androides (Ridley Scott, 1982) -, os filmes chegam até aos espectadores por intermédio do canal da verossimilhança: "somos, na verdade, tomados por um sentimento profundo e contraditório de nossa semelhança e de nossa dessemelhança. Parecemo-nos ao mesmo tempo externos e idênticos a nós mesmos, eu e não eu, ou enfim, o ego alter"31. Mas o interesse aqui não é a circulação e recepção das imagens, mas como elas são simbolicamente feitas, o que dizem sobre os fenômenos que retratam e a partir de quais referenciais estéticos, filosóficos e culturais foram influenciadas organicamente.

Em Planeta dos Macacos, astronautas humanos chegam a um planeta habitado por macacos e são escravizados. Quando um deles escapa e vira objeto de estudo a obra fílmica parte para o princípio da alegoria como categoria estimulante da imaginação sonhadora. O homem - que é o ser evoluído do macaco - é aprisionado 
por macacos desenvolvidos - seres primitivos na ótica dos astronautas que se desenvolveram - e vira objeto de estudo. $\mathrm{O}$ fato dos astronautas se tornarem objeto de estudo remete a noção de que a ciência objetifica as coisas para entendê-las, nesse caso, numa grande virada filosófica para compreender os caminhos da humanidade. No filme Blade Runner - $\mathrm{O}$ caçador de androides, um policial caça e extermina humanos criados artificialmente. Com o desejo de sair da corporação, Deckard se vê em uma situação em que deve fazer o serviço e ao mesmo tempo julgar quem é humano e androide. Aqui está outro exemplo da face filosófica da dualidade humana: quando o ser humano se desenvolve ao ponto de criar humanoides precisa identificar as sutis semelhanças e diferenças. Ambos os filmes de ficção científica usam signos alegóricos para criar imaginários de futuro distópico.

Morin $^{32}$ sobre o potencial afetivo das imagens fílmicas dirá que “todas as cargas afetivas e mágicas latentes estão presentes tanto no cinematógrafo quanto na fotografia. Mas a imagem fotográfica se adaptou às particularidades individuais. Ao contrário de quem frui a foto, quem frui um filme não pode se considerar proprietário da imagem". Longe disso, "o cinematógrafo se depura em relação à fotografia, de inúmeras fixações provindas da apropriação particular" ${ }^{33}$.

O canal da verossimilhança que os filmes têm com os espectadores se faz no movimento das imagens, criando a sensação de representação da realidade objetiva-subjetiva da vida. $\mathrm{O}$ jogo da ficção com o "real" faz com que o material fílmico contenha efeito híbrido: o que os filmes mostram são recriações da realidade social e a imaginação dos mundos possíveis da criação artística.

Como discutido, no exercício da linguagem cinematográfica, o diretor de cinema e, depois, o montador, modelam tempo e espaço fílmicos. Podemos investigar as imagens simbólicas dos filmes de ficção, pois os filmes tratam o espaço de duas formas, podendo reproduzi-los no movimento da câmera e produzi-los criando um espaço total a partir dos espaços fragmentários ${ }^{34}$.

$\mathrm{Na}$ análise dos espaços reproduzidos visualizamos os ângulos, detalhes, curvas, cantos que a câmera registra, com zoom-in, plano detalhe, dentre outras técnicas. O que querem dizer essas filmagens em cenários pequenos, qual a importância simbólica destas imagens do silêncio? No caso dos espaços produzidos, investiga-se os espaços sintéticos, que falam genericamente sobre o conteúdo distintivo do filme (ver Figura 3). Nesse tratamento fílmico do espaço, a representação do espaço identicamente é a do tempo. A espacialidade do tempo é consubstanciada na modelação do espaço reproduzido. Perceber essa dinâmica espaçotemporal, com ou sema existência da trilha sonora, serve-nos para compreender o discurso fílmico. O tempo afetivo das pessoas reserva o gesto da modalidade do tempo relacional. Nos filmes são do tempo afetivo a criação de signos alegóricos em mensagens singulares para a compreensão do discurso fílmico. Fruto de uma série de tentativas orgânicas da cinematografia mundial, os espaços em tempos afetivos falam sem a necessidade da presença objetiva de enunciação da mensagem sobre os espaços reproduzidos.

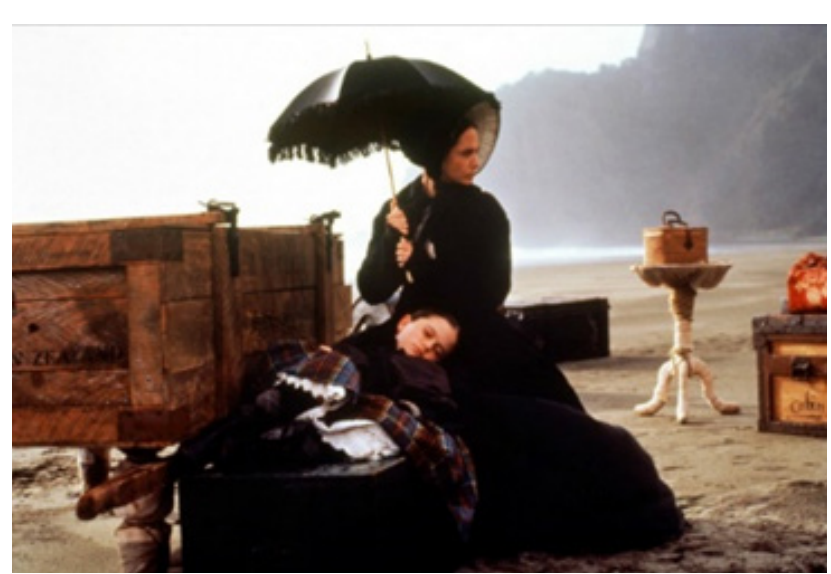

32 Op. cit., p. 54.

33 Ibid., p. 54.

34 MARTIN, op. cit. 

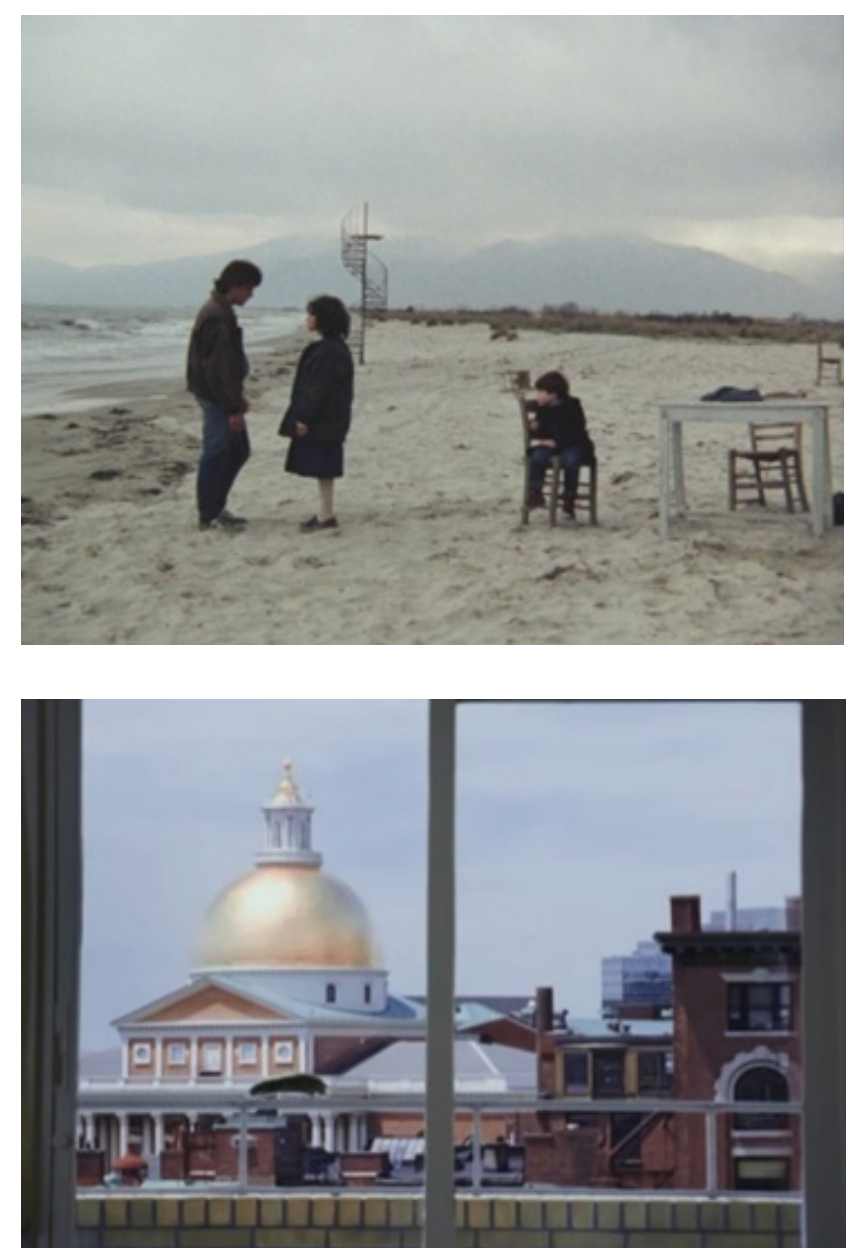

Figura 3 - frames dos filmes O Piano, Paisagem na Neblina e Os Infiltrados. Fonte: Jan Chapman Productions | Paradis Films | Plan B Entertainment, Initial Entertainment Group (IEG) e Vertigo Entertainment.

A Figura 3 expõe espaços temporais reproduzidos em movimentos de câmera no domínio da dimensão simbólica da imagem fílmica. No frame de O Piano (Jane Campion, 1993), duas mulheres vestidas de preto estão sentadas e encostadas no piano. Aparentam estar esperando por alguém. No cenário tem caixa de madeira, baús enormes e mesinha que permanecem ao fundo: estão de mudança. Mas o ambiente natural da praia chuvosa não combina com suas vestimentas e nem com a classe social algo de muito transformador está acontecendo na vida dessas duas mulheres. No frame de Paisagem na Neblina (Theodoros Angelopoulos, 1988), duas crianças conversam com um homem. Na praia onde estão tem móveis para sentar - uma mesa e duas cadeiras, uma delas mais distante. As duas crianças estão procurando por algo. No frame de
Os Infiltrados (Martin Scorsese, 2006), a terceira imagem, o movimento da câmera caminha pelo apartamento e em zoom-in focaliza na cúpula da igreja enquanto um rato atravessa a linha inferior da imagem em frente a câmera, encarnando à imagem fílmica um papel alegórico do discurso cinematográfico trabalhada até aquele momento da obra. Os três filmes resumem bem sobre a presença de signos alegóricos na imagem fílmica para a construção do discurso fílmico.

\section{Imaginação, Cinema e Antropologia}

A imaginação é um rudimento na criação de mundos fílmicos. Segundo Robert Desnos (2018, p. 257), "do desejo do sonho participam o gosto e o amor pelo cinema. Na falta da aventura espontânea que nossas pálpebras deixarão fugir ao despertar, vamos às salas escuras em busca do sono artificial e talvez do estimulante capaz de povoar nossas noites solitárias". Maria Luiza Souza (2014, p. 5), a respeito de etnografia da recepção fílmica agrega dizendo que "um filme também é aquilo que fazemos dele, o que sentimos e como interpretamos ao que assistimos, seja na sala escura, seja ao abrigo de nossas casas". Conclusivamente, estudos de cinema são estudos da recepção fílmica, embora não façamos uma ciência da recepção fílmica dos espectadores, nós mesmos, enquanto intérpretes e analistas do discurso cinematográfico estamos envolvidos nas imagens dos filmes.

Para Antropologia do Cinema, filmes de ficção são olhares da sociedade e da cultura de um povo, a forma adotada para representálas são as narrativas que constroem símbolos e signos alegóricos originados pela linguagem cinematográfica. Fazer uma socioantropologia do cinema é conceber a expressão como modalidade criativa da imaginação. Para interpretar obras cinematográficas o pesquisador deverá entrar no campo da imaginação.

A representação da sociedade pela linguagem cinematográfica se dá na construção da representação do pensamento em signos alegóricos. Ao analisar signos alegóricos construídos nos filmes se pode captar como que 
a sociedade está sendo imaginada coletivamente por metáforas. Fiz isso de forma razoável com os filmes das figuras 1, 2 e 3. Noções do espaço nas obras de Méliès e Kubrick, por exemplo, criaram estatutos referenciais simbólicos: Viagem à Lua, em 1902, e 2001: Uma Odisseia no Espaço, em 1968, conceberam discursos dos seus tempos históricos, respectivamente, os voos pioneiros de Santos Dumont - em 1901 - e dos irmãos Wright - em 1903 -, e a corrida espacial nos EUA e União Soviética - a partir de 1957. Todas essas imagens nutrem o Weltbild em narrativas duráveis, em repetições complexas de signos permanentes (DURAND, 1997). Então, a ligação entre contextos fílmicos será a permanência de símbolos, códigos e alegorias. A permanência dessas simbologias é objeto para a Antropologia do Cinema. No cinema, existem mais aproximações do que distanciamentos: os filmes estão ligados por uma superestrutura de ideias e imaginações ressignificadas por mudanças na sociedade e cabe desconstruir a ideologia presente no discurso do filme de ficção para analisar o complexo imaginário que as representações guardam (KRACAUER, 1989).

Méliès se valeu da imaginação ao conceber imagens do céu e da terra, perguntando-se "como será" o espaço sideral? O cinema de ficção tem representado imaginações sobre o espaço sideral de muitas maneiras. Recentemente, $O$ Primeiro Homem (Damien Chazelle, 2018) representou os primeiros passos do homem na lua, e Perdido em Marte (Ridley Scott, 2015) esvaziou as possibilidades ficcionais de um astronauta que "se perdeu" no planeta vermelho. Sonhos e imaginações que os diretores se empenharam em filmar: Alfonso Cuarón com a alegoria em Gravidade (2013), Andrei Tarkovsky com a poesia existencial em Solaris (1972), e George Lucas com a aventura social em Star Wars: Episódio IV - Uma Nova Esperança (1977). Tanto Méliès quanto Kubrick, Chazelle, Scott, Cuarón, Tarkovsky e Lucas imaginaram o espaço e o universo em períodos diferentes e utilizando tecnologias revolucionárias. O que aproxima todos estes filmes é a criação de mundos baseados no imaginário.
A aproximação de todos esses filmes com os primeiros filmes de aventura de Méliès evidencia a vontade de imaginar situações com um argumento iminentemente social, até mesmo em obras de ficção-científica, como estas que tenho citado. Notadamente, os termos fictícios dobra - viajar longas distâncias na velocidade da luz ou próximo a ela - e salto - escolha de ponto específico para chegar a um determinado lugar - sofreram ressignificações em obras como Guardiões da Galáxia (James Gunn II, 2014), Looper - Assassinos do Futuro (Rian Johnson, 2012), Jumper (Doug Liman, 2008) e Efeito Borboleta (Eric Bress e J. Mackye Gruber, 2004). Quando dobras e saltos não são proporcionados por tecnologias ultrarrevolucionárias, são incentivados por fenômenos sobre-humanos e pelo contato com objetos de memórias como fotografias.
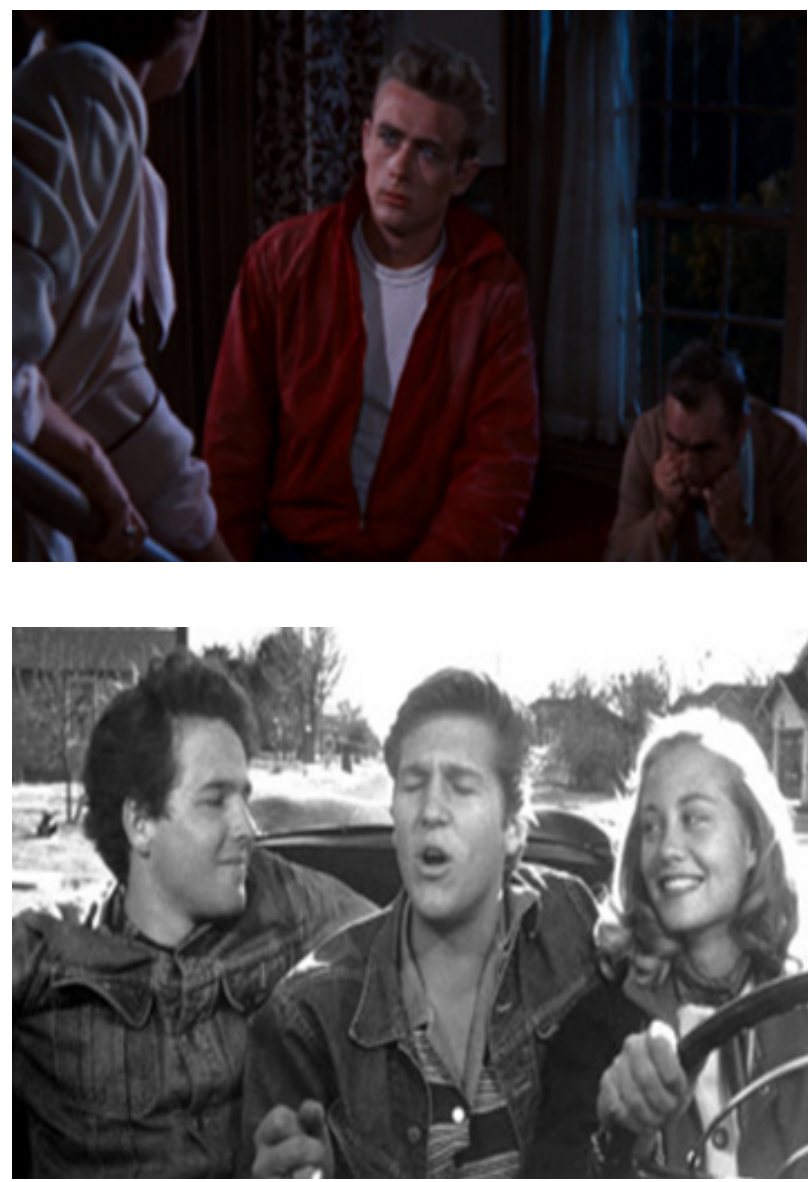

Figura 4 - frames dos filmes Juventude Transviada e A Última Sessão de Cinema. Fonte: Warner Bros. | BBS Productions 
Como visto nos filmes citados, o imaginário social transforma-se em um imaginário fílmico de ideias, sensações, desejos e modos de comportamento. No cinema norte-americano dos anos 1950-60 filmes de ficção voltados para o público juvenil mostraram gravidez na adolescência, drogas, violência doméstica e conflitos psicológicos com narrativas, personagens, histórias e trilha sonora que possibilitaram veicular situações sociais da realidade no cinema. Juventude Transviada (Nicholas Ray, 1955) representou a figura do jovem irado, Jim Stark, ícone dos anos cinquenta para a juventude norte-americana (Figura 4). Como se pensava a adolescência antes do filme de Nicholas Ray? Como foi pensada a juventude estadunidense depois do filme A Última Sessão de Cinema (Peter Bogdanovich, 1971)? Se não fossem os filmes de John Hughes, O Clube dos Cinco (1985) e Curtindo a Vida Adoidado (1986), como a idade escolar seria imaginada, já nos anos 80 ? Filmes teen mais recentes como $17 \mathrm{Outra} \mathrm{Vez}$ (Burr Steers, 2009) lidam com figuras arquetípicas construídas por um arsenal simbólico de filmes que se engajaram na manutenção e construção de personagens sociais escolares.

Essas figuras arquetípicas são mais imaginárias do que propriamente arquetípicas, arraigadas no inconsciente dos espectadores - e não são genericamente reprodutíveis em todas as culturas; mas a presença recorrente delas nos filmes, na publicidade, na música, na moda, na gastronomia, em todos os veículos de comunicação, afirma um lugar de coexistência com os comportamentos sociais da existência. A socioantropologia do cinema dá realce a essas aproximações, aos discursos originados nas narrativas para compreender a sociedade e a cultura.

Juventude Transviada projetou o estilo, comportamento e os medos de uma juventude dos anos 1950, abrindo possíveis conexões entre realidade e ficção e como ambas podem iniciar um movimento cultural arraigado nas relações sociais. A própria figura de Jim Stark permeia produções que dialogam com o tema da juventude. Em O Clube dos Cinco, alunos são obrigados a conviver uma tarde de sábado na escola. São pessoas com estilos e pensamentos diferentes, mas com o tempo começam a reconhecer a singularidade do outro. Marco considerável no cinema teen, Curtindo a Vida Adoidado é narrado por Ferris Bueller. O processo de identificação das histórias e dos personagens com situações da adolescência transborda nos filmes para além da circulação de noções da juventude. Ao construir vidas ficcionais, o cinema teen elabora uma ideia de vida na medida em que carrega sonhos e desejos dessa mesma juventude retratada. O que dizem imaginários e signos alegóricos em todos esses filmes que tratam da juventude; quais os problemas, questões e paradigmas estes elementos trazem ao discurso fílmico? Como signos alegóricos são digeridos na narrativa fílmica? São perguntas que podemos fazer ao se analisar na abordagem socioantropológica um filme de ficção.

Assim como aconteceu com a idade escolar, as temáticas da violência - nos filmes do norteamericano Quentin Tarantino (Bastardos Inglórios, 2009) -, de classe - nos filmes do espanhol Luis Buñuel (Os Esquecidos, 1950; O Discreto Charme da Burguesia, 1972) -, do religioso - nos filmes do dinamarquês Carl Theodor Dreyer (O Martírio de Joana d'Arc, 1928; A Palavra, 1955) -, da existência (nos filmes do sueco Ingmar Bergman ( $O$ Sétimo Selo, 1957; Vergonha, 1968) - ou do social e do político - nos filmes do brasileiro Glauber Rocha (Deus e o Diabo na Terra do Sol, 1964; Terra em Transe, 1967) - encontraram um espaço em filmes emblemáticos da cinematografia mundial, regando encontros entre filmes com imagens complexas do ponto de vista dos imaginários e signos alegóricos.

\section{Considerações finais}

Filmes de gênero dos mais distintos, como os de ficção-científica, noir e os expressionistas podem oferecer um acervo antropológico imaginário da imaginação humana para a investigação dos pesquisadores de Antropologia. Analisei brevemente filmes que tratam da 
questão do universo e da juventude para oferecer um quadro das possibilidades vigentes e já há muito estudadas do cinema. A partir da reflexão do tempo e do espaço fílmicos e dos processos de imaginação entendemos o cinema como um lugar de expressão das sensibilidades humanas, das ideias e das imaginações sonhadoras dos diretores e da equipe de cinema. A socioantropologia do cinema, nos termos de Morin, busca verificar e interpretar as mensagens escondidas do contexto fílmico. Entrar verdadeiramente nas linhas divisórias entre o entretenimento e o imaginário, o visível e o simbólico da imagem fílmica. Compreender como estão sendo construídos os imaginários e signos alegóricos das sociedades e culturas representadas é um dos caminhos da socioantropologia do cinema.

Assim, busquei administrar os imaginários e signos alegóricos como componentes centrais para uma socioantropologia do cinema, com base em uma perspectiva filosófica das imagens fílmicas. Gaston Bachelard e Gilbert Durand dão grande importância à imaginação sonhadora e aos signos alegóricos para se compreender a sociedade e cultura. Escolhi trazê-los para o campo do audiovisual porque os estudos de cinema necessitam de um norte voltado para a filosofia do repouso. Como defendido no início, o caminho foi desvendar evidências simbólicas do discurso e das imagens fílmicas e creditar à fenomenologia fílmica um potente instrumento de empiria das sociedades representadas. Nesse painel geral, a contribuição deste ensaio aos estudos cinematográficos na Antropologia reside em aproveitar-se do devaneio poético dos filmes de ficção que impregnam de imaginários e signos alegóricos o discurso fílmico. Partindo desse lugar de análise se pode alcançar o momento em que as imagens tocam o real.

\section{Referências bibliográficas}

ALTMANN, Eliska. "Verdade, tempo e autoria: três categorias para pensar o filme etnográfico". In: Revista Anthropológicas, vol. 20 $(1+2)$, ano 13,2009 , p. 57-79.
ARAÚJO, Alberto Filipe; TEIXEIRA, Maria Cecília Sanchez. "Gilbert Durand e a pedagogia do imaginário". In: Letras de Hoje, Porto Alegre, v. 44, n. 4,2009 , p. 7-13.

BACHELARD, Gaston. A dialética da duração. São Paulo: Editora Ática, 1988b.

A poética do devaneio. São Paulo: Martins Fontes, 1988a.

A poética do espaço. São Paulo: Martins Fontes, 1993.

O ar e os sonhos: ensaio sobre a imaginação do movimento. São Paulo: Martins Fontes, 2001.

BAZIN, André. "Ontologia da imagem fotográfica" e "O mito do cinema total". In: . In: O que é o cinema? São Paulo: Ubu Editora, 2018. p. 26-35, p. 36-42.

CABRERA, Júlio. O cinema pensa: uma introdução à filosofia através dos filmes. Rio de Janeiro: Rocco, 2006.

CAIUBY NOVAES, Sylvia. "Imagem e ciências sociais: trajetória de uma relação difícil". In: BARBOSA, Andréa.

CUNHA, Edgar. HIKIJI, Rose. (Orgs.). In: Imagem-conhecimento: antropologia, cinema $e$ outros diálogos. Campinas: Papirus, 2009. p. 3560.

CERTEAU, Michel de. A invenção do cotidiano: artes de fazer. Petrópolis: Vozes, 2014.

COSTA, Antonio. Compreender o cinema. São Paulo: Globo, 2003.

COSTA, Flávia Cesarino. "Primeiro cinema". In: MASCARELLO, Fernando. (Org.). In: História do Cinema Mundial. Campinas: Papirus, 2006. p. 17-52. 
COSTA, Wendell Marcel Alves da. "Casa Onírica: cinema de ficção como acervo antropológico imaginário”. In: ROCHA, Gabriel Kafure. (Org.). In: Bachelard, um livro vivo (Homenagem aos 135 anos de nascimento do Filósofo). Goiânia: Editora Phillos, 2019a. p. 302331.

"Um cinema de cidade: imagens do urbanismo em filmes brasileiros". In: Sociabilidades Urbanas - Revista de Antropologia e Sociologia, v. 3, n. 7, março, 2019b, p. 97-112.

DESNOS, Robert. "O sonho e o cinema”. In: XAVIER, Ismail. (Org.). In: A experiência do cinema (antologia). Rio de Janeiro/São Paulo: Paz e Terra, 2018. p. 257-258.

DIDI-HUBERMAN, Georges. "Quando as imagens tocam o real". In: Pós: Belo Horizonte, v. 2, n. 4, 2012, p. 204-219.

DURAND, Gilbert. As estruturas antropológicas do imaginário: introdução à arqueologia geral. São Paulo: Martins Fontes, 1997.

A imaginação simbólica. Lisboa: Edições 70, 1993.

O imaginário: ensaio acerca das ciências e da filosofia da imagem. Rio de Janeiro: DIFEL, 2004.

GOFFMAN, Erving. A representação do eu na vida cotidiana. Petrópolis: Vozes, 1985.

HIKIJI, Rose Satiko Gitirana. Imagemviolência: etnografia de um cinema provocador. São Paulo: Terceiro Nome, 2012.

KRACAUER, Siegfried. Teoría del cine: la redención de la realidade física. Barcelona: Ediciones Paidós, 1989.

MARTIN, Marcel. A linguagem cinematográfica. São Paulo: Brasiliense, 2013.
MENEZES, Paulo. "Cinema: imagem e interpretação". In: Tempo Social, Rev. Sociol. USP, vol. 8, n. 2, outubro, 1996, p. 83-104.

- "Sociologia e cinema: aproximações teórico-metodológicas". In: Teoria e Cultura: Revista do Programa de Pós-Graduação em Ciências Sociais da Universidade Federal de Juiz de Fora, v. 12, n. 2, jul./dez., 2017, p. 17-36.

MORIN, Edgar. O cinema ou o homem imaginário: ensaio de antropologia sociológica. São Paulo: É Realizações, 2014.

MUNSTERBERG, Hugo. "A memória e a imaginação". In: XAVIER, Ismail. (Org.). In: A experiência do cinema (antologia). Rio de Janeiro/ São Paulo: Paz e Terra, 2018. p. 33-41.

PEIXOTO, Clarice. "A antropologia visual no Brasil". In: Cadernos de Antropologia e Imagem, n. 1, 1995, p. $75-80$.

PITTA, Danielle Perin Rocha. Iniciação à teoria do imaginário de Gilbert Durand. Rio de Janeiro: Atlântico Editora, 2005.

PUDOVKIN, Vsevolod. "Os métodos de cinema”. In: XAVIER, Ismail. (Org.). In: $A$ experiência do cinema (antologia). Rio de Janeiro/ São Paulo: Paz e Terra, 2018. p. 59-62.

REYNA, Carlos P. “Antropologia do Cinema: as narrativas cinematográficas na pesquisa antropológica". In: Teoria e Cultura, v. 12, n. 2, jul./dez, 2017, p. 37-51.

ROCHA, Ana Luiza Carvalho da; ECKERT, Cornelia. "Imagem recolocada: pensar a imagem como instrumento de pesquisa e análise do pensamento coletivo". In: Iluminuras, v. 2, n. 3, 2001, p. 2-13.

A preeminência da imagem e do imaginário nos jogos da memória coletiva em coleções etnográficas. Brasília: ABA, 2015. 
SAMPAIO, Bruno; DUARTE, Eduardo. "Um devaneio pelos vapores poéticos de Viagem Porque Preciso, Volto Porque Te Amo". In: Esferas, ano 4, n. 6, 2015, p. 131-140.

SANTOS, Myrian Sepúlveda dos. "Orfeu Negro: entre fantasia e realidade". In: Cadernos de Antropologia e Imagem, Rio de Janeiro, vol. 11, n. 2, 2000, p. 33-48.

SARTRE, Jean-Paul. O existencialismo é um humanismo. São Paulo: Nova Cultural, 1987.

SORLIN, Pierre. Sociología del Cine. México: Fondo de Cultura Económica, 1977.

SOUZA, Maria Luiza Rodrigues. "Modos de ver e viver o cinema: etnografia da recepção fílmica e seus desafios". In: Revista Brasileira de Estudos de Cinema e Audiovisual, vol. 3, n. 5, jan./ jun, 2014, p. 1-16.

TARKOVSKI, Andrei. Esculpir o tempo. São Paulo: Martins Fontes, 2010.

TURNER, Victor. Dramas, campos e metáforas: ação simbólica na sociedade humana. Niterói: Editora UFF, 2008.

WUNENBURGER, Jean-Jacques. ARAÚJO, Alberto. "Introdução ao imaginário". In: ARAÚJO, Alberto. BAPTISTA, Fernando. (Orgs.). In: Variações sobre o imaginário. Domínios, teorizações, práticas hermenêuticas. Lisboa: Instituto Piaget, 2003. p. 23-44.

\section{Filmografia}

17 Outra Vez (Burr Steers, 2009)

2001: Uma Odisseia no Espaço (Stanley Kubrick, 1968)

A Chegada de Um Trem à Estação (Auguste e Louis Lumière, 1895)

A General (Buster Keaton, 1926)
A Grande Ilusão (Jean Renoir, 1937)

A Palavra (Carl Theodor Dreyer, 1955)

A Última Sessão de Cinema (Peter Bogdanovich, 1971)

Bastardos Inglórios (Quentin Tarantino, 2009)

Blade Runner - O caçador de androides (Ridley Scott, 1982)

Crônica de Um Verão (Jean Rouch, 1961)

Curtindo a Vida Adoidado (John Hughes, 1986)

Deus e o Diabo na Terra do Sol (Glauber Rocha, 1964)

Efeito Borboleta (Eric Bress e J. Mackye Gruber, 2004)

Gravidade (Alfonso Cuarón, 2013)

Guardiões da Galáxia (James Gunn II, 2014)

Intolerância (D.W. Griffith, 1916)

Jumper (Doug Liman, 2008)

Juventude Transviada (Nicholas Ray, 1955)

Looper - Assassinos do Futuro (Rian Johnson, 2012)

M, O Vampiro de Dusseldorf (Fritz Lang, 1931)

Nanook, o Esquimó (Robert J. Flaherty, 1922)

O Clube dos Cinco (John Hughes, 1985)

O Discreto Charme da Burguesia (Luis Buñuel, 1972)

O Grande Roubo do Trem (Edwin Porter, 
O Martírio de Joana d'Arc (Carl Theodor Dreyer, 1928)

O Nascimento de Uma Nação (D.W. Griffith, 1915)

O Piano (Jane Campion, 1993)

O Primeiro Homem (Damien Chazelle, 2018)

O Sétimo Selo (Ingmar Bergman, 1957)

Os Esquecidos (Luis Buñuel, 1950)

Os Infiltrados (Martin Scorsese, 2006)

Paisagem na Neblina (Theodoros Angelopoulos, 1988)

Perdido em Marte (Ridley Scott, 2015)

Planeta dos Macacos (Franklin J. Schaffner, 1968)

Sem Novidade no Front (Lewis Milestone, 1930)

Solaris (Andrei Tarkovsky, 1972)

Star Wars: Episódio IV - Uma Nova Esperança (George Lucas, 1977)

Terra em Transe (Glauber Rocha, 1967)

The Kiss (George Albert Smith, 1899)

Vergonha (Ingmar Bergman, 1968)

Viagem à Lua (Georges Méliès, 1902)

Viagem Através do Impossível (Georges Méliès, 1904) 